\title{
Binding patterns of seminal plasma plasma proteins on bovine epididymal and ejaculated sperm membrane*
}

\author{
[Topografia de ligação de proteínas do plasma seminal à membrana de espermatozoides \\ bovinos epididimários e ejaculados] \\ C.E.A. Souza ${ }^{1,2}$, A.A. Moura ${ }^{1,2}$, A.C. Lima-Souza ${ }^{1,2}$, G.J. Killian ${ }^{2}$ \\ ${ }^{1}$ Departamento de Zootecnia, Universidade Federal do Ceará, Fortaleza, CE \\ ${ }^{2}$ J.O. Almquist Research Center - Department of Dairy and Animal Science \\ The Pennsylvania State University, \\ University Park, PA, USA 16802
}

\begin{abstract}
The present study was designed to investigate the topographical distribution of seminal plasma (SP) proteins on epididymal and ejaculated bovine sperm. Using immunocytochemistry and confocal microscopy the binding patterns of bovine SP proteins BSP-A3, albumin, transferrin, prostaglandin Dsynthase (PGDS) and nucleobindin in ejaculated and cauda epididymal sperm from adult bulls were evaluated. Experiments were performed using sperm from 5 males. Data showed a positive signal, only detected for anti-PGDS, in the acrosomal cap of epididymal and ejaculated sperm. In ejaculated sperm, a very weak signal for nucleobindin 2 in the midpiece and equatorial regions was detected, using the antirat nucleobindin. BSP-A3 was detected on all sperm regions studied, with a more evidenced signal in acrosome and midpiece. However, no binding was detected for albumin or transferrin in neither epididymal nor ejaculated sperm. In conclusion, PGDS, BSP-A3 and nucleobindin interact directly with bovine sperm, with specific topographic distribution. These findings may add to the knowledge of how these proteins modulate sperm functions, thus providing fundamental support for studies designed to evaluate how they influence sperm functions.
\end{abstract}

Keywords: sperm, seminal plasma proteins, immunocytochemistry

\section{RESUMO}

Investigou-se a distribuição topográfica da ligação de proteínas seminais à membrana de espermatozoides bovinos epididimários e ejaculados. Utilizando imunocitoquímica e microscopia confocal, avaliaram-se a topografia de ligação das proteínas BSP-A3, albumina, transferrina, prostaglandina $D$ sintetase (PGDS) e nucleobindina 2 (NUC2) à membrana espermática. Os experimentos foram realizados utilizando espermatozoides de cinco touros. Os resultados mostraram que, para espermatozoides epididimários, somente detectou-se a PGDS na crista do acrossomo. Nos espermatozoides ejaculados, a PGDS ligou-se de forma mais intensa à crista acrossômica, enquanto a NUC2 apresentou sinal bastante fraco na peça intermediária e região equatorial. A BSP-A3 ligou-se a todas as regiões estudadas, de forma mais intensa na peça intermediária e acrossomo. Nenhum sinal foi detectado para albumina ou transferrina, seja em espermatozoides epididimários ou ejaculados. Concluiu-se que PGDS, BSP-A3 e NUC2 interagem diretamente com espermatozoides bovinos, e mostrou distribuição topográfica específica. Estes achados permitem melhor compreensão sobre o papel desempenhado por essas proteínas na regulação da função espermática e da fertilidade.

Palavras-chave: espermatozoide, proteínas do plasma seminal, imunocitoquímica

Recebido em 10 de março de 2010

Aceito em 28 de março de 2011

E-mail: ceazevedo@gmail.com; amoura@ufc.br

*This article was funded by USDA grants 2003-34437-13460 and 2004-34437-15106. The first author received a fellowship awarded by the Brazilian Research Council (CAPES) 


\section{INTRODUCTION}

Seminal plasma proteins have been implicated in several sperm functions, including capacitation and acrosome reaction (Thérien et al., 1995; Siciliano et al., 2008). The intensity of selected protein spots in 2-D maps of seminal plasma (Killian et al., 1993), accessory sex gland fluid (Moura et al., 2006a) and cauda epididymal fluid (Moura et al., 2006b) is related to the fertility of dairy bulls as well. Furthermore there is a relationship of these proteins with the in vitro penetration of bovine oocytes (Moura et al., 2007a).

Recently, it has been reported that fertilityassociated proteins from bull accessory gland fluid (AGF), such as osteopontin, BSP-30kDa and BSP-A1/A2 (Killian et al., 1993; Moura et al., 2006a; 2007ab) are able to bind ejaculated sperm membrane and remain attached to the cells, even after contact with oviductal fluids (Souza et al., 2008). These findings brought new insights to the proposed models of how these proteins affect sperm function, and fertilization itself.

Likewise, a comprehensive analysis of the proteome of bovine cauda epididymal fluid has been conducted, identifying a very diverse set of proteins, such as lipocalin-type prostaglandin D synthase (PGDS), albumin, transferrin and nucleobindin (Moura et al., 2007c). PGDS has been reported to be more prevalent in the seminal plasma of high fertility bulls (Killian et al., 1993; Gerena et al., 1998). Although there is only one form of PGDS detectable in 2-D gels of bovine seminal plasma, in the cauda epididymal fluid (CEF) PGDS is composed by a series of four spots, which comprise $7.6 \%$ of all protein spots quantified in the CEF gels (Moura et al., 2007b). Three of these PGDS isoforms, however, were found to be 2 to 3-fold more abundant in the CEF of low fertility males (Moura et al., 2006b). Although these findings seem contradictory, one possible explanation would be that proteins from the AGF could modify some of these isoforms during ejaculation.

Also, albumin represents $21 \%$ of all proteins detected in 2-D maps of bovine CEF (Moura et $a l ., 2007 c$ ) and transferrin is one of the major epididymal proteins as well (Dacheux et al., 2006). Such proteins are associated with sperm quality and fertility in several species (Bernstein, 1987; Moura et al., 2007b), although the precise mechanisms involved in their actions are not completely elucidated.

In addition to the previously mentioned proteins, our research group was the first to describe the presence of nucleobindin in both the AGF (Moura et al., 2007a) and CEF (Moura et al., 2007b). This protein is a multifunctional calcium-binding protein and participates in activation of intracellular signaling pathways, cell-cell interaction and apoptosis, among other events (Valencia et al., 2008), but its role in the reproductive tract is still unknown. Thus, secretions of both AGF and CEF contain proteins that directly or indirectly affect sperm functions. In this regard, the knowledge of interactions between such proteins and the sperm will bring valuable information about their role in reproduction.

The present study was conducted to investigate the binding ability and topographical distribution of certain seminal plasma proteins on epididymal and ejaculated bovine sperm.

\section{MATERIAL AND METHODS}

Binding patterns of bovine seminal plasma proteins BSP-A3, albumin, transferrin, prostaglandin D-synthase and nucleobindin were analyzed in ejaculated and cauda epididymal sperm from adult bulls. Ejaculated sperm were collected from 5 mature Holstein bulls using an artificial vagina. Epididymal sperm was collected from 5 other Holstein males at a local slaughterhouse. The binding of each protein on sperm was evaluated by immunocytochemistry and confocal laser scanning microscopy.

The analysis of ejaculated sperm was conducted with semen from reproductively normal, mature Holstein bulls. After the collection with an artificial vagina, the semen was kept in a water bath at $37^{\circ} \mathrm{C}$ and an aliquot was evaluated for motility, to ensure that the semen had at least $90 \%$ of motile cells. Samples were centrifuged (700 $\mathrm{x} g$ for $15 \mathrm{~min}$ ) to separate the seminal plasma, and the sperm pellet was then washed in two additional centrifugations with modified Tyrode's medium (MTM; Parrish et al., 1988). To obtain cauda epididymal sperm, the epididymis and vas deferens from five 
slaughtered Holstein sires were dissected from the testes. After cutting the vas deferens approximately $5 \mathrm{~cm}$ from the cauda of the epididymis, PBS was flushed back to the epididymis with a syringe and a small incision was made at the cauda wall to allow the release of the cauda milieu. Cauda sperm was then obtained through the centrifugation of this cauda secretion to separate cells from cauda fluid (700 $\mathrm{x} g$ for $15 \mathrm{~min}$ ). Following this first separation, cauda sperm was washed with MTM, as done with samples of ejaculated sperm. After the washings, we collected aliquots of both ejaculated and epididymal samples to determine sperm concentration using a hemocytometer (Souza et al., 2008).

For immunocytochemistry, both ejaculated and cauda epididymal sperm samples, each containing $5 \times 10^{6}$ cells, were fixed in paraformaldehyde (2\%) for 10 minutes and washed twice in PBS (700 g, 15 min., $4^{\circ} \mathrm{C}$ ), as previously described (Souza et al., 2008). To block non-specific sites, spermatozoa were next incubated for 2 hours, under gentle agitation at $4^{\circ} \mathrm{C}$, in PBS-Tween 20 containing $5 \%$ of bovine serum albumin (BSA; Sigma, USA). Sperm cells were then incubated with the primary antibodies in the same blocking solution for 2 hours (under gentle agitation and $4^{\circ} \mathrm{C}$ ), using the following antibody concentrations: 1:100 for antitransferrin, 1:200 for anti-PGDS and anti-BSP A3 and 1:250 or 1:500 for anti-nucleobindin. After this first incubation sperm were washed three times with PBS-Tween 20 (500 g, $5 \mathrm{~min}$, $4^{\circ} \mathrm{C}$ ) and incubated with the secondary antibody, a FITC-conjugated anti-IgG (1:300, Sigma Inc., Saint Louis, USA) for 1 hour in a solution with PBS-Tween 20 and 1\% BSA. Three washes followed this incubation (as described above) and smears were immediately prepared in a dark room, using an anti-fade reagent (Invitrogen Corp., Carlsbad, USA), for confocal analysis.

Antibody against BSP-A3 was purified from respective rabbit anti-sera (Moura et al., 2007a), kindly provided by Dr. Puttaswamy Manjunath (Department of Medicine, University of Montreal, Canada). In summary, a column with protein-A Sepharose matrix (Sepharose CL-4B; Sigma Co., St. Louis, MO, USA) was washed initially with $50 \mathrm{mM}$ PBS containing $0.15 \mathrm{M}$ $\mathrm{NaCl}(\mathrm{pH}$ 7.4) and adsorbed proteins were eluted with Glycine- $\mathrm{HCl}$ (pH 2.5). Fractions with absorbance at $280 \mathrm{~nm}$ were pooled, which contained basically immunoglobulins, including the anti-BSP antibodies, and immediately adjusted to $\mathrm{pH} 7.4$ with $0.1 \mathrm{~N} \mathrm{NaOH}$. The antibody solution was then fractioned and stored at $-20^{\circ} \mathrm{C}$ until use.

Polyclonal antibody against recombinant PGDS was generated in New Zealand rabbits, where the IgG fraction of the serum was separated using protein-A matrix chromatography (Gerena et al., 2000). For nucleobindin, two different antibodies were chosen, one produced against bovine nucleobindin (Somogyi et al., 2004), kindly provided by Dr. Mikael Wendel (Center for Oral Biology, Karolinska Institute, Sweden), and another directed against human nucleobindin 2 and purchased from GenWay Biotech (San Diego, USA). Anti-bovine transferrin and antiBSA were affinity-isolated and generated in rabbit, according to manufactory's description (Sigma Inc., St Louis, MI, USA). For all studies, controls were conducted using incubations of sperm cells with only the first or second antibody, and with no antibody.

Images of sperm treated with FITC-conjugated antibodies were acquired by a laser scanning confocal microscopy using an emission wavelength of $510 \mathrm{~nm}$, and Fluoview ${ }^{\mathrm{TM}}$ software (Fluoview 300 Confocal Microscope, Olympus Inc., Center Valley, USA). Images were obtained as a series of sequential planes taken every $0.125 \mu \mathrm{m}$, with a total depth of $5 \mu \mathrm{m}$ (Souza et al., 2008). The image stacks were deconvoluted to improve the resolving power and to eliminate noises and out-of-focus blur, using AutoDeblur \& AutoVisualize version 9.3 (Media Cybernetics Inc., Silver Springs, MD, USA). Five cells were analyzed for each origin (epididymis and ejaculate) and for each antibody treatment. The average pixel intensity of all sequential planes taken from each cell were compared among different regions of sperm and between ejaculated and epididymal sperm by Duncan statistical test (SAS, 2003).

\section{RESULTS}

For epididymal sperm, a positive signal was detected only for the antibody against PGDS, bound to the upper segment of the sperm acrosome (Fig. 1). On ejaculated sperm, this binding pattern of anti-PGDS was also found, but 
the intensity of fluorescence was higher $(\mathrm{p}<0.05)$ than that quantified for epididymal sperm (Fig. 2). Interaction of nucleobindin was only seen on ejaculated sperm, restricted to the midpiece and equatorial regions, using the antibody directed against bovine nucleobindin (Fig. 3). The antihuman nucleobindin 2 did not show any reaction to sperm cells from any source.

Anti-BSP A3 was detected in the midpiece, acrosomal and equatorial regions of ejaculated sperm (Fig. 4), but the signal was more intense $(\mathrm{p}<0.05)$ in the acrosome and midpiece when compared to that of the equatorial region (Fig. 5).

No binding could be detected for antibodies against albumin or transferrin in either epididymal or ejaculated bovine sperm. No detectable fluorescence was visualized when sperm cells were incubated with only the first or second antibody, and with no antibody (Fig. 6).

\section{DISCUSSION}

Using the cauda epididymal fluid and ejaculated sperm, the presence of proteins previously described in other different tissues was assessed, which could be important in reproduction. A detailed description of the binding patterns of BSP A1/A2 and BSP 30kDa proteins for bovine sperm membrane has been previously reported (Souza et al., 2008). In this study, immunoreactivity patterns are described for these proteins in ejaculated sperm and after incubation with isthmic and ampullary oviductal fluids. The aforementioned proteins strongly bound to the acrosomal and equatorial regions of the sperm head and to the midpiece of intact sperm, however, have a positive reaction in the acrosomal region for acrosome-reacted sperm could not be detected (Souza et al., 2008).

In the present study a similar binding pattern for BSP-A3 was detected, confirming prior reports that BSP-A3 binds to different regions of ejaculated bovine sperm, but it is not found on epididymal sperm membrane (Manjunath et al., 1993). This protein originates from the vesicular glands (Manjunath et al., 1988) and interacts with the sperm during ejaculation, more specifically with membrane choline-containing phospholipids (Desnoyers and Manjunath, 1992), a step that initiates sperm capacitation (Thérien et al., 1995). Identically to the other BSPs, BSPA3 might remain attached to the sperm membrane until the oviduct (Souza et al., 2008), where it is involved in the formation of the sperm reservoir (Gwathmey et al., 2006). Thus, the localization of this protein suggests its importance over sperm function and further studies must be performed to delineate how it acts upon fecundation.

A positive binding of PGDS to the acrosome of both epididymal and ejaculated sperm is also described in this study. Immunocytochemistry studies confirmed that PGDS interacts with the acrosomal region of ejaculated bovine sperm; however, it is still unclear whether PGDS bounds to epididymal sperm or not (Gerena et al., 2000). The present study is the first to report that PGDS reacts with cauda epididymal sperm. Moreover, given that this protein is synthesized by the testis and epididymis and there is no evidence of its expression by the AGF (Gerena et al., 1998; Fouchécourt et al., 1999; Moura et al., 2006b; 2007a), the PGDS observed bound to ejaculated sperm, as observed in this study, indicates that the protein is already linked to sperm in the epididymal milieu. The specific role played by PGDS in male fertility is still a matter of speculation, but it has been suggested that it works as a transporter of lipophilic substances, such as retinol, across testis/epididymal-blood barriers and to the sperm (Leone et al., 2002). Negative relationships exist between the intensity of PGDS spots detected in the CEF 2-D electrophoresis maps and non-return rates of dairy bulls (Moura et al., 2006a), while positive associations were detected between PGDS spot intensity in 2D maps of seminal plasma and bull fertility (Killian et al., 1993). Other researchers found positive correlations between seminal plasma PGDS and sperm motility in the man (Chen et al., 2005; 2007a). Regardless of the fact that some of these results are contradictory, the existence of empirical associations between PGDS and reproductive traits suggests that this protein does influence male fertility. 
Binding patterns of seminal...
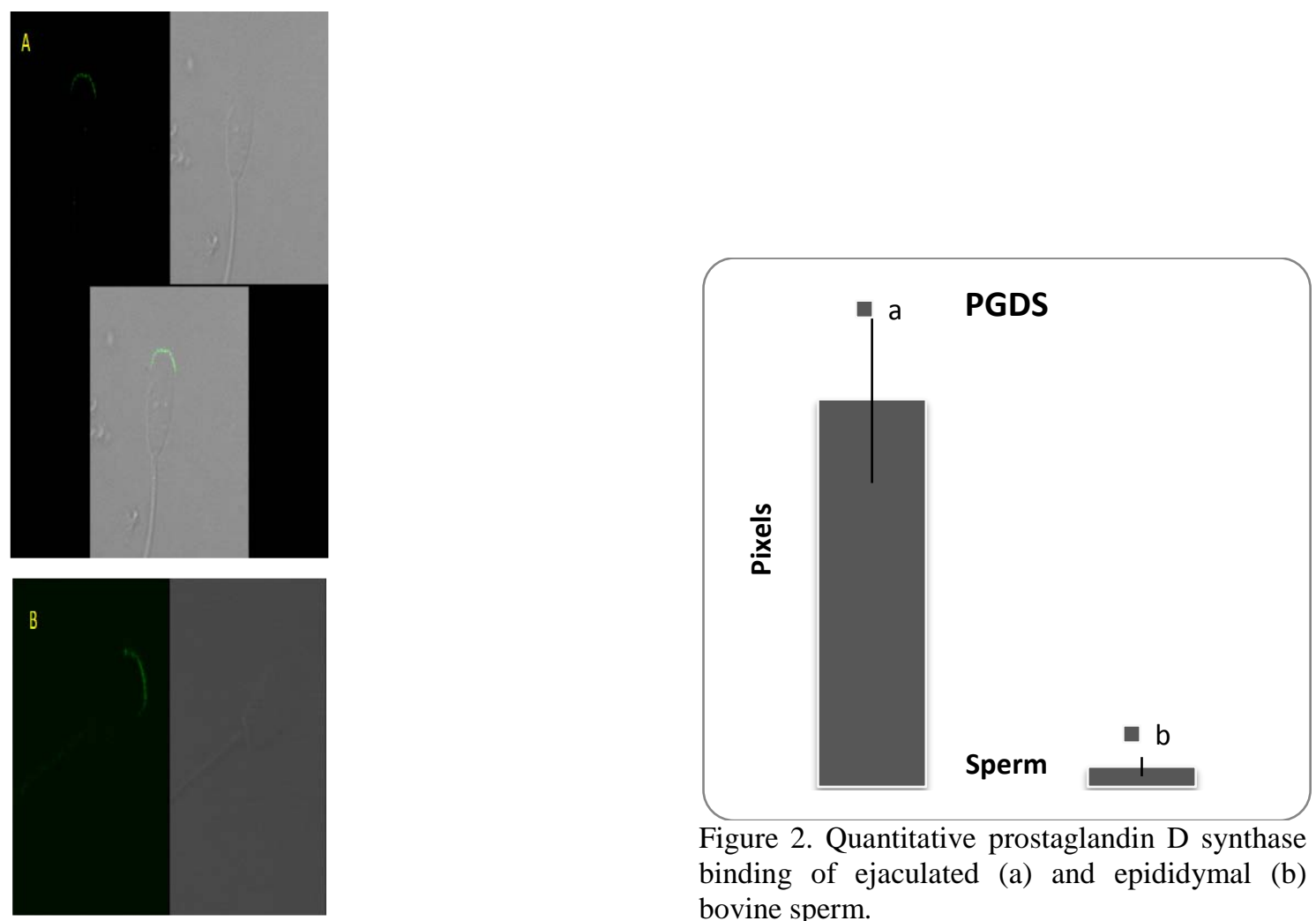

Figure 2. Quantitative prostaglandin D synthase binding of ejaculated (a) and epididymal (b) bovine sperm.

Figure 1. Prostaglandin D synthase binding of ejaculated (a) and epididymal (b) bovine sperm. Images obtained through indirect immunofluorescence and laser scanning confocal microscopy.

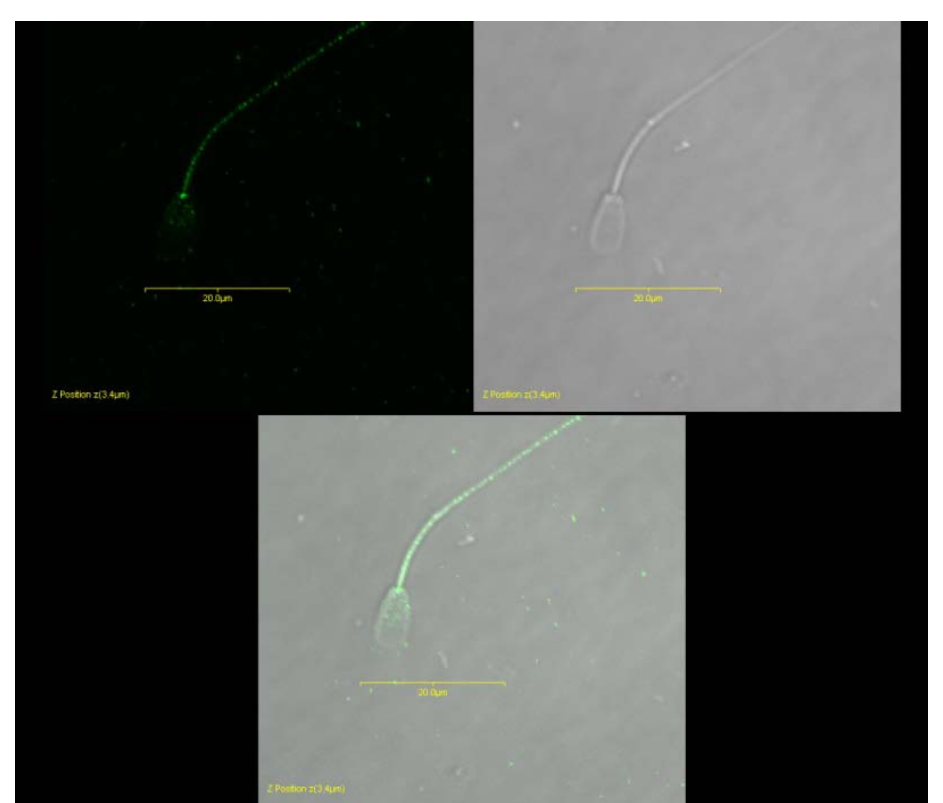

Figure 3. Binding pattern of nucleobindin 2 of ejaculated bovine sperm. Images obtained through indirect immunofluorescence and laser scanning confocal microscopy. 


\section{Souza et al.}
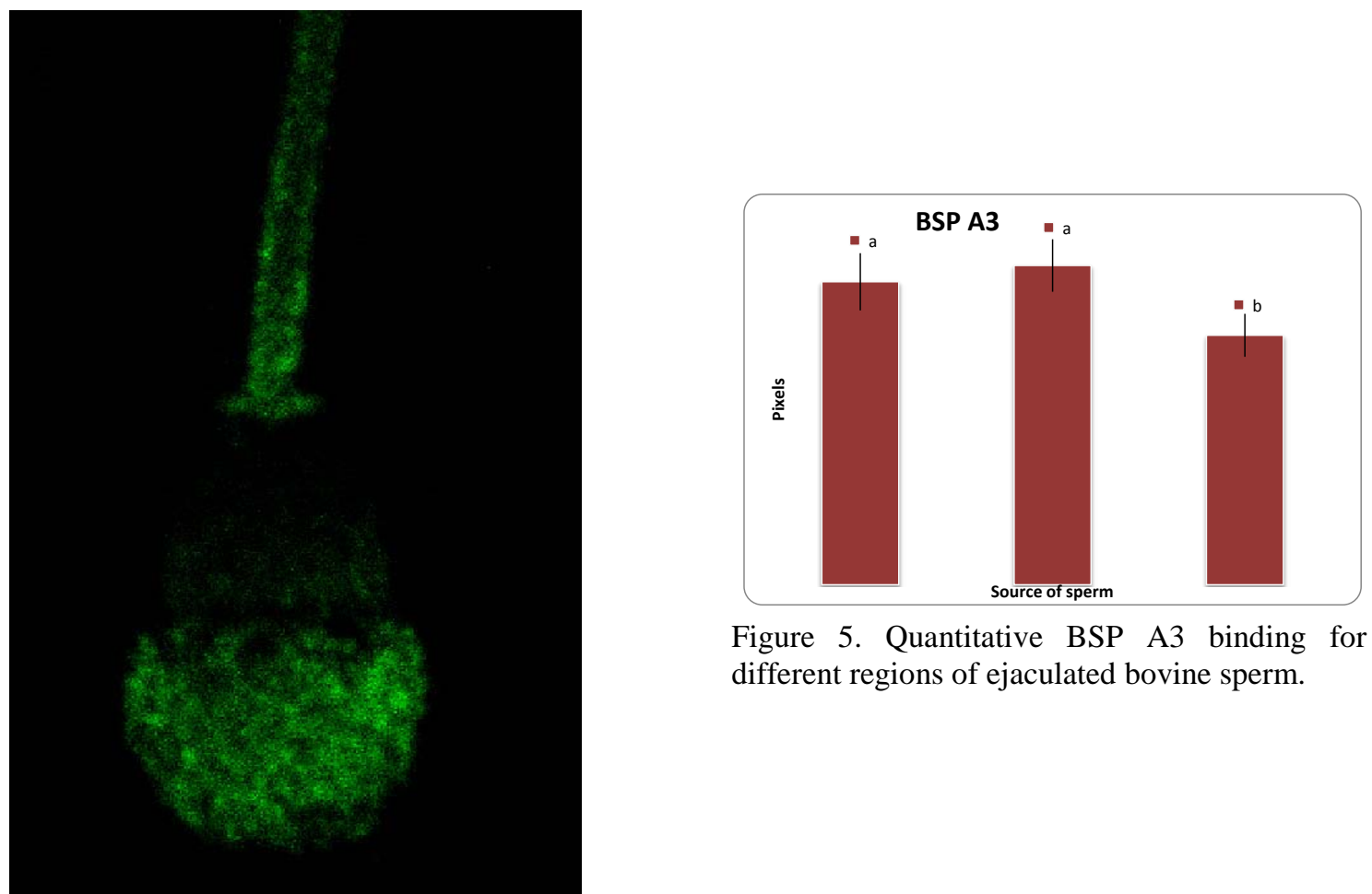

Figure 5. Quantitative BSP A3 binding for different regions of ejaculated bovine sperm.

Figure 4. Binding pattern of BSP A3 of ejaculated bovine sperm. Images were obtained through indirect immunofluorescence and laser scanning confocal microscopy.

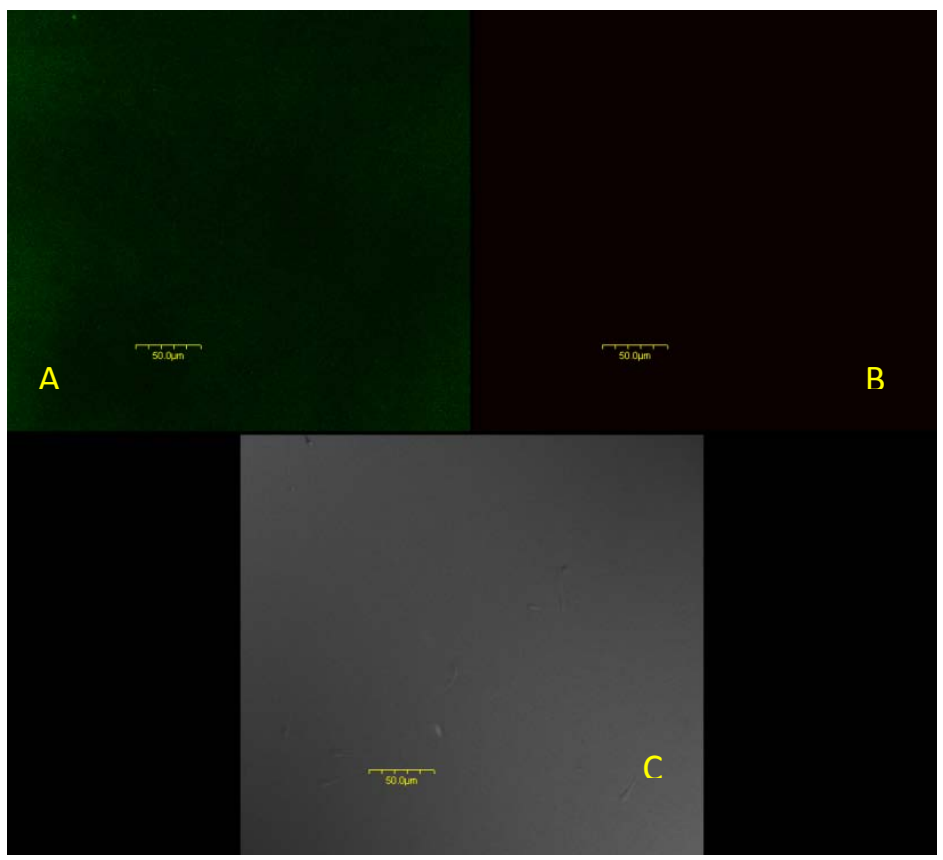

Figure 6. Laser scanning confocal microscopy images of the controls, containing only the fluorescent antibody. No detectable fluorescence can be seen in the fluorescent (a), visible (b) and mixed (c) channels. 
In addition, information shown here about PGDS binding to sperm acrosome before and after ejaculation supports the notion that PGDS may affect sperm not only while it is stored in the cauda epididymis, but also at and/or after ejaculation, with potential consequences to gamete viability in the female reproductive tract.

Another protein observed in the present experiment is the nucleobindin, which can be found in different organs, such as central nervous system, colon and in the extracellular matrix of bones and teeth (Somogyi et al., 2004; Chen et al., 2007b; Foo et al., 2008), and has the ability to bind calcium, trigger intracellular signaling pathways and mediate apoptosis-related processes, among other roles (Valencia et al., 2008). It is possible that nucleobindin could play a role in sperm capacitation, due to its involvement with calcium influx. Thus, the presence of this protein in ejaculated sperm could indicate its importance on the reproductive tract. Indeed, the presence of nucleobindin 2 in the AGF (Moura et al., 2007a) and CEF (Moura et al., 2007b) of the bull was already reported. In addition, there is practically no information about the role of nucleobindin in the male reproductive tract, and herein this work brings new information about this protein's interaction with the midpiece of ejaculated sperm, suggesting that the multifunctional nucleobindin may in fact influence sperm metabolism.

Additionally, transferrin and albumin are some of the most abundant proteins in the cauda epididymal fluid from bulls (Moura et al., 2007c) and other species, such as humans and rams (Dacheux et al., 2006). Transferrin is only present in the epididymal secretion while albumin is present in both cauda epididymal and accessory sex gland fluids from mature bulls (Moura et al., 2006a; Moura et al., 2007a). The presence of transferrin in the epididymis could be explained by the fact that this protein is involved in a scavenging strategy and prevents damages caused by excessive iron. Also, transferrin is likely important for normal reproduction given that a lower expression of this protein correlates with a high occurrence of defective sperm in rats (Bernstein et al., 1987) and infertility in men (Holmes et al., 1982). Regarding albumin, it has several roles in the male, including the stimulation of both sperm motility (Akerlöf et al., 1989) and acrosome reaction (Singleton and Killian, 1983) and protection of sperm membrane against lipid peroxidation (Armstrong et al., 1998). Further results obtained in the present study clearly define that neither transferrin nor albumin binds to either epididymal or ejaculated sperm, despite the abundance of these two epididymal components. This observation suggests that transferrin and albumin influence the sperm function in the epididymis and at ejaculation by mechanisms independent of binding to the sperm.

Given this scenario, it may be intriguing to visualize how albumin would participate in acrosome reaction without binding to the cell. However, such event occurs in the oviduct and not at ejaculation and both isthmus and ampulla fluid, express high amounts of albumin (Souza et al., 2007). This albumin, in turn, could then bind to sperm given their membrane has gone through several structural modifications by the time sperm reaches the oviduct and enough evidence exists to show that capacitation does change sperm membrane (Manjunath and Thérien, 2002).

In conclusion, binding patterns of BSP A3, lipocalin-type prostaglandin D-synthase, transferrin, albumin and nucleobindin to epididymal and ejaculated sperm were evaluated. BSP A3 is expressed only in the AGF (Thérien and Manjunath, 2003), PGDS and transferrin only in the bovine CEF (Moura et al., 2007ab), while albumin and nucleobindin are components of both secretions. The present study shows evidence that BSP A3, PGDS and nucleobindin physically interact with sperm, either epididymal and/or ejaculated sperm. However, transferrin and albumin, despite their abundance in reproductive fluids of mature bulls, do not bind to sperm. These findings provide fundamental support for studies designed to evaluate how those seminal plasma proteins influence sperm functions. 


\section{REFERENCES}

AKERLÖF, E.; FREDRICSSON, B.; GUSTAFSON, O. et al. Serum factors stimulate the motility of human spermatozoa. Int. J. Androl., v.12, p.124-130, 1989.

ARMSTRONG, J.S.; RAJASEKARAN, M.; HELLSTROM, W.J. et al. Antioxidant potential of human serum albumin: role in the recovery of high quality human spermatozoa for assisted reproductive technology. J. Androl., v.19, p.412419, 1998.

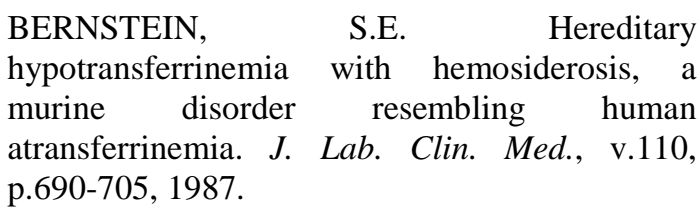

CHEN, D.Y.; WANG, J.J.; HUANG, Y.F. et al. Relationship between lipocalin-type prostaglandin D synthase and $\alpha$-glucosidase in azoospermia seminal plasma. Clin. Chim. Acta, v.354, p.534-541, 2005.

CHEN, D.Y.; ZHU, M.; CUI, Y.D. et al. Relationship between contents of lipocalin-type prostaglandin D synthase on the surface of infertility sperm and in seminal plasma. Biochemistry (Mosc.), v.72, p.215-218, 2007a.

CHEN, Y.; LIN, P.; QIU, S. et al. Autoantibodies to $\mathrm{Ca}^{2+}$-binding protein calnuc is a potential marker in colon cancer detection. Int. J. Oncol., v.30, p.1137-1144, 2007b.

DACHEUX, J.L.; BELGHAZI, M.; LANSON, $\mathrm{Y}$. et al. Human epididymal secretome and proteome. Mol. Cell. Endocrinol., v.250, p.3642, 2006.

DESNOYERS, L.; MANJUNATH, P. Major proteins of bovine seminal plasma exhibit novel interactions with phospholipid. J. Biol. Chem., v.267, p.10149-10155, 1992.

FOO, K.S.; BRISMAR, H.; BROBERGER, C. Distribution and neuropeptide coexistence of nucleobindin-2 mRNA/nesfatin-like immunoreactivity in the rat CNS. Neuroscience, v.156, p.563-579, 2008.

FOUCHÉCOURT, S.; DACHEUX, F.; DACHEUX, J.L. Glutathione-independent prostaglandin $D_{2}$ synthase in ram and stallion epididymal fluids: origin and regulation. Biol. Reprod., v.60, p.558-566, 1999.
GERENA, R.L.; EGUCHI, N.; URADE, Y. et al. Stage and region-specific localization of lipocalin-type prostaglandin D synthase in the adult murine testis and epididymis. J. Androl., v.21, p. 848-854, 2000.

GERENA, R.L.; IRIKURA, D.; URADE, Y. et al. Identification of a fertility-associated protein in bull seminal plasma as lipocalin-type prostaglandin D synthase. Biol. Reprod., v.58, p.826-833, 1998.

GWATHMEY, T.M.; IGNOTZ, G.G.; MUELLER, J.L. et al. Bovine seminal plasma proteins PDC-109, BSP-A3, and BSP-30-kDa share functional roles in storing sperm in the oviduct. Biol. Reprod., v.75, p.501-507, 2006.

HOLMES, S.D.; LIPSHULTZ, L.I.; SMITH, R.G. Transferrin and gonadal dysfunction in man. Fertil. Steril., v.38, p.600-604, 1982.

KILLIAN, G.J.; CHAPMAN, D.A.; ROGOWSKI, L.A. Fertility-associated proteins in Holstein bull seminal plasma. Biol. Reprod., v.49, p.1202-1207, 1993.

LEONE, M.G.; HAQ, H.A.; SASO, L. Lipocalin type prostaglandin D-synthase: which role in male fertility? Contraception, v.65, p.293-295, 2002.

MANJUNATH, P.; BAILLARGEON, L.; MARCEL, Y.L. et al. Diversity of novel proteins in gonadal fluids. In: CHRÉTIEN, M.; McKERNS, K.W. (Eds.). Molecular biology of brain and endocrine peptidergic system. New York: Plenum, 1988. p.259-273.

MANJUNATH, P.; CHANDONNET, L.; LEBLOND, E. et al. Major proteins of bovine seminal vesicles bind to spermatozoa. Biol. Reprod., v.49, p.27-37, 1993.

MANJUNATH, P.; THÉRIEN, I. Role of seminal plasma phospholipid-binding proteins in sperm membrane lipid modification that occurs during capacitation. J. Reprod. Immunol., v.53, p.109-119, 2002.

MOURA, A.A.; KOC, H.; CHAPMAN, D.A. et al. A comprehensive proteomic analysis of the accessory sex gland fluid from mature Holstein bulls. Anim. Reprod. Sci., v.98, p.169-188, 2007a. 
MOURA, A.A.; KOC, H.; CHAPMAN, D.A. et al. Identification of proteins in the accessory sex gland fluid associated with fertility indexes of dairy bulls: a proteomic approach. J. Androl., v.27, p.201-211, 2006a.

MOURA, A.A.; KOC, H.; CHAPMAN, D.A. et al. Proteins of the cauda epididymal fluid associated with fertility of mature dairy bulls. $J$. Androl., v.27, p.534-541, 2006b.

MOURA, A.A.; CHAPMAN, D.A.; KILLIAN, G.J. Proteins of the accessory sex glands associated with the oocyte-penetrating capacity of cauda epididymal sperm from Holstein bulls of documented fertility. Mol. Reprod. Dev., v.74, p.214-222, 2007b.

MOURA, A.A.; SOUZA, C.E.A.; ARAÚJO, A.A. et al. Strategies to study the proteome of cauda epididymal fluid of bulls: two-dimensional gel electrophoresis, albumin depletion and mass spectrometry. In: CONGRESSO BRASILEIRO DE REPRODUÇÃO ANIMAL, 17., Belo Horizonte, 2007. Anais... Belo Horizonte, MG: [CBRA] 2007c. p.40. (Resumo).

PARRISH, J.J.; SUSKO-PARRISH, J.L.; WINER, M.A. et al. Capacitation of bovine sperm by heparin. Biol. Reprod., v.38, p.11711180, 1988.

SAS Institute Inc., 2003. SAS/STAT ${ }^{\circledR}$. User's Guide, Version $6,4^{\text {th }}$ Edition, v.2. SAS Institute Inc., Cary, NC.

SICILIANO, L.; MARCIANÒ, V.; CARPINO, A. et al. Prostasome-like vesicles stimulate acrosome reaction of pig spermatozoa. Reprod. Biol. Endocrinol., v.6, p.5-11, 2008.
SINGLETON, C.L.; KILLIAN, G.J. A study of phospholipase in albumin and its role in inducing the acrosome reaction of guinea pig spermatozoa in vitro. J. Androl., v.4, p.150-156, 1983.

SOMOGYI, E.; PETERSSON, U.; SUGARS, R.V. et al. Nucleobindin - a $\mathrm{Ca}^{2+}$-binding protein present in the cells and mineralized tissues of the tooth. Calcif. Tissue Int., v.74, p.366-376, 2004.

SOUZA, C.E.A.; MOURA, A.A.; MONACO, E. et al. Binding patterns of bovine seminal plasma proteins A1/A2, 30kDa and osteopontin on ejaculated sperm before and after incubation with isthmic and ampullary oviductal fluid. Anim. Reprod. Sci., v.105, p.72-89, 2008.

SOUZA, C.E.A.; MOURA, A.A.; MONACO, E. et al. Protein profile of the oviductal fluid from cyclic cows. In: ANNUAL MEETING OF THE SOCIETY FOR THE STUDY OF REPRODUCTION, 40., 2007, San Antonio, TX. Proceedings... San Antonio, [s.n.] 2007. p.230. (Abstract).

THÉRIEN, I.; BLEAU, G.; MANJUNATH, P. Phosphatidylcholine-binding proteins of bovine seminal plasma modulate capacitation of spermatozoa by heparin. Biol. Reprod., v.52, p.1372-1379, 1995.

THÉRIEN, I.; MANJUNATH, P. Effect of progesterone on bovine sperm capacitation and acrosome reaction. Biol. Reprod., v.69, p.14081415, 2003.

VALENCIA, C.A.; COTTEN, S.W.; DUAN, J. et al. Modulation of nucleobindin-1 and nucleobindin-2 by caspases. FEBS Lett., v.582, p.286-290, 2008. 